\title{
SEED GERMINATION OF Pouteria torta (MART.) RADLK. SUBESP. torta IN DIFFERENT ENVIRONMENTAL CONDITIONS
}

\author{
José Carlos Pina, Ademir Kleber Morbeck de Oliveira*
}

Graduate Studies Program in Environment and Regional Development, Anhanguera-Uniderp University, Campo Grande, Mato Grosso do Sul, Brazil - e-mail: josecarlospina@gmail.com; akmorbeckoliveira@gmail.com*

Received for publication: 21/04/2018 - Accepted for publication: 23/08/2019

\begin{abstract}
Resumo
Germinação de sementes de Pouteria torta (Mart.) Radlk. subesp. torta em diferentes condições ambientais. A germinação é considerada uma etapa crítica no processo de produção de mudas para a recuperação ambiental. Desta maneira, entender o comportamento germinativo de espécies nativas com potencial de utilização econômico, contribui com o desenvolvimento dos elos da cadeia de sementes e mudas florestais. Levando-se em consideração as poucas informações sobre a espécie arbórea Pouteria torta subesp. torta, objetivou-se com este trabalho avaliar a germinação de sementes e formação de plântulas normais, utilizando diferentes substratos e temperaturas. O experimento foi conduzido em laboratório de pesquisa, combinando-se dois substratos (sobre papel e vermiculita) e seis temperaturas $\left(20,25,30,35,20-30\right.$ e $\left.25-35^{\circ} \mathrm{C}\right)$, em câmara de germinação, com delineamento experimental inteiramente casualizado, em esquema fatorial (2x6). A avaliação foi diária, verificando-se a emissão de raiz primária, vigor das sementes e formação de plântulas. Os resultados indicaram que, nas melhores condições, o processo de protrusão da raiz primária ocorreu após 20 dias de teste, com o tempo de germinação prolongando-se por mais de dois meses. Os resultados obtidos indicaram que ocorreu interação de fatores, sendo que a utilização de substrato vermiculita e temperaturas de 35 e $25-35{ }^{\circ} \mathrm{C}$ produziu as melhores taxas de germinação e índice de velocidade de germinação, enquanto substrato papel, 30 e $35^{\circ} \mathrm{C}$, melhor tempo médio de germinação. Levando-se em consideração às variáveis: germinação, índice de velocidade de germinação e formação de plântulas normais, as temperaturas de 35 e $25-35{ }^{\circ} \mathrm{C}$, substrato vermiculita, são as mais adequadas para a produção de mudas de Pouteria torta subesp. torta.
\end{abstract}

Palavras-chave: Sapotaceae; guapéva; formação de plântulas.

\begin{abstract}
Germination is considered a critical step in the seedling production process aiming the recovery of environments. Thus, understanding the germination behavior of native species with potential for economic use contributes to the development of the forest seed and seedling chain. Considering the limited information on the tree species Pouteria torta subesp. torta, this study aimed to evaluate its seed germination and formation of normal seedlings using different temperatures and substrates. The experiment was conducted in germination chamber in a research laboratory using two substrates (paper and vermiculite) and six temperatures $(20,25,30$, $35,20-30$ and $25-35{ }^{\circ} \mathrm{C}$ ) in a completely randomized design in a $2 \times 6$ factorial arrangement. Daily evaluation was conducted to verify primary root emission, seed vigor, and seedling formation. The results indicated that the primary root protrusion process began after 20 days of testing under the best conditions, with germination time lasting longer than two months. The results obtained also showed that there was interaction between factors, with use of the vermiculite substrate and the temperatures of 35 and $25-35{ }^{\circ} \mathrm{C}$ producing the best germination rates and germination speed index, and use of the paper substrate and the temperatures of 30 and $35^{\circ} \mathrm{C}$ showing the best mean germination time. Considering the analyzed variables (germination, germination speed index, and formation of normal seedlings), the temperatures of 35 and $25-35{ }^{\circ} \mathrm{C}$ and the vermiculite substrate are the most suitable for the production of Pouteria torta subesp. torta seedlings.

Keywords: Sapotaceae; guapevá; seedling formation.
\end{abstract}

\section{INTRODUCTION}

Sapotaceae, belonging to genus Pouteria, is among the families of economic and medicinal importance of the Cerrado biome. It is widespread and used to obtain wood for civil construction and in mixed plantations destined to the restoration of degraded areas, with leaves and fruits for use in folk medicine as antidiarrheal and antimicrobial, as well as for use as food (fruits) (CARVALHO, 2008; ELIAS et al., 2013).

Pouteria torta (Mart.) Radlk. subsp. torta, popularly known as 'guapéva', 'abiú' or 'pêssego-do-mato', stands out among the species of this genus. The largest trees can reach $35 \mathrm{~m}$ in height and $100 \mathrm{~cm}$ in trunk diameter, 
occurring from Amapá to Santa Catarina states, in the Atlantic Forest and Cerrado biomes; it is considered a late secondary or climax species, and is cultivated in orchards for the use of its fruits (CARVALHO, 2008).

The Cerrado flora is one of the richest in biodiversity in the world; it has a high degree of endemism and is considered a hotspot for constant threat to its ecosystem, caused by anthropogenic impacts (GRECCHI et al., 2014). Thus, studies and projects have been intensified to recover areas and avoid aggravation of previously detected problems, which resulted in increased seed commercialization and demand for seedlings of native tree species. However, there is still lack of information on the germination behavior of many species, such as Pouteria torta (Mart.) Radlk. subsp. torta.

However, for the production of seedlings used in areas under recovery processes and of economic use, it is necessary to know the factors that affect the seed germination process of the species, such as light, temperature and water availability (external, environmental factors) or dormancy (internal, intrinsic factor).

The seed germination process includes a sequence of physiological events that are influenced by external (environmental) and internal (dormancy and germination inhibitors and promoters) factors, and each of these factors can act on its own or in interaction with others. This process is considered a biological phenomenon, a result of resumption of embryo growth with subsequent rupture of the integument by the primary root (BEWLEY et al., 2013).

Germination tests may include the use of different environmental factors to evaluate the viability and vigor of a seed lot. The information obtained can be used in forest nurseries to accelerate and homogenize the processes, enabling the production of more seedlings in a shorter time. According to Dousseau et al. (2008) and Bewley et al. (2013), the most relevant environmental factors for the germination process are water, light, temperature and substrate type. Typically, temperature and substrate variations are the most commonly used to indicate the best conditions for obtaining higher germination rates and normal seedling formation.

Temperature influences the process by affecting the biochemical reactions that determine the entire germination process, changing the final percentage of seed germination and seed vigor (BEWLEY et al., 2013). Some species germinate best at constant temperatures, whereas others alternate high and low germination rates depending on the region of origin of the seeds. According to Brancalion et al. (2013), most of the species in the Cerrado biome previously researched germinate better at approximately $25^{\circ} \mathrm{C}$.

The type of substrate and its water retention capacity also influence germination, varying according to its composition. Its function is to provide the seeds with adequate moisture for germination and subsequent seedling formation (DOUSSEAU et al., 2008; BRASIL, 2009). The choice of substrate should consider seed size and moisture requirement, and paper and vermiculite are the most commonly used substrates in laboratory tests (BRASIL, 2009).

Each species has specific requirements, but information on the germination processes of most Brazilian tree species is still scarce, hindering the use of reliable and standardized analysis methods (BRASIL, 2009). For species Pouteria torta, Salomão et al. (2003) described a germination rate of $25 \%$, not to mention the germination conditions (substrate type and temperature used). This information shows that, despite its importance as a species with great exploitation potential, little is known about the aspects related to the germination and emergence of Pouteria torta subsp. torta seedlings.

In this context, this study aimed to test the hypothesis that seed germination of Pouteria torta subsp. torta is favored by the presence of higher temperatures and substrates with greater water retention; to this end, it evaluated different substrates and temperatures on the germination and formation of normal seedlings of this species.

\section{MATERIAL AND METHODS}

Botanical material was collected (December 2016) from Legal Preservation areas in the Parque dos Poderes region (20²6'16.6” S; 54³2'14.5” W), municipality of Campo Grande, state of Mato Grosso do Sul, Brazil. The collection region belongs to the Cerrado biome, with presence of seasonal forests, regular and dense cerrado areas, and gallery forests, and predominance of planted pastures (Brachiaria spp.) for beef cattle raising. Ten matrices of species Pouteria torta subsp. torta were used, considering size (height $>5 \mathrm{~m}$ ) and minimum distance between trees $(>1 \mathrm{~km})$.

A voucher specimen was mounted and used in the process of species confirmation, by analytical key and specialized bibliography, and deposited as a taxonomic document at the Anhanguera-Uniderp University herbarium (no. 8512). The collected material was sent to the Research Laboratory on Environmental Systems and Biodiversity and seed water content was determined by the oven method at $105 \pm 3{ }^{\circ} \mathrm{C}$ for $24 \mathrm{~h}$ (BRASIL, 2009) using four repetitions of 10 seeds. On average, the lots weighed $60.81 \mathrm{~g}$ before the drying process, that is, 6.081 $\pm 0.001 \mathrm{~g} \mathrm{seed}^{-1}$. According to Carvalho (2008), these seeds can be considered large and there is thus need for adaptation to the Seed Analysis Rules (SAR). 
After manual removal of the fruit pulp, the seeds were immersed in $1 \%$ sodium hypochlorite for 3 min and then washed in running water for $1 \mathrm{~min}$. Using previously sterilized materials, the disinfected seeds were distributed in transparent plastic boxes $(11 \times 11 \times 3.5 \mathrm{~cm})$ on two substrates, paper (two sheets of Germitest ${ }^{\circledR}$ paper) and vermiculite, and kept in germination chamber under six temperatures $\left(20,25,30,35,20-30\right.$ and $\left.25-35^{\circ} \mathrm{C}\right)$ and two light conditions: $12 \mathrm{~h}$ constant white-light ( $\pm 660 \mathrm{lux})$ and $12 \mathrm{~h}$ constant darkness. When necessary, the substrates were moistened with distilled water. Due to the occurrence of fungi in certain treatments, the seeds were washed with sodium hypochlorite and the substrates were replaced and moistened with an aqueous solution containing $0.2 \%$ iprodione fungicide.

Evaluation was performed daily considering the germination of seeds with primary root emission $>2 \mathrm{~mm}$ (OLIVEIRA et al., 2014), and the non-germinated seeds were evaluated by the tetrazolium test (BRASIL, 2009) with modifications. Germination percentage and seed vigor were quantified (mean germination time in days MGT and germination speed index - GSI), as well as the relative frequency of germination (used for the substrate with the best results, vermiculite). The initial seedling growth was determined by measuring the size of the primary root (seedling collar to the apical meristem of the root system, in $\mathrm{mm}$ ) and shoot part (seedling collar to the apical meristem, in $\mathrm{mm}$ ) were analyzed using a digital caliper.

The experimental design was completely randomized, with four replications of 25 seeds per treatment, in a 2x6 factorial arrangement (substrate $x$ temperature). The values were initially tested for the assumptions of normality of residues and homogeneity between variances. When these assumptions were not met, the data were transformed and analysis of variance (ANOVA) was applied using the Tukey's test (5\%). The data were processed using the Assistat software. For a better understanding of the results, the means presented in the tables correspond to unprocessed data.

\section{RESULTS}

The seeds of Pouteria torta subsp. torta had $36.2 \%$ water content. (unipolar)

The species presents hypogeal germination, with reserve cotyledons (phanerocotyledonar) and axis

The results indicated that there was interaction between factors, with use of the vermiculite substrate and the temperatures of 35 and $25-35^{\circ} \mathrm{C}$ providing the best germination rates and germination speed index, and use of the paper substrate and the temperatures of 30 and $35{ }^{\circ} \mathrm{C}$ showing the best mean germination time. Considering the analyzed variables (germination, germination speed index, and formation of normal seedlings), the temperature of $35^{\circ} \mathrm{C}$ and the vermiculite substrate are the most suitable for the production of Pouteria torta subsp. torta seedlings.

Table 1. Analysis of variance, germination (G\%), germination speed index (GSI) and mean germination time in days (MGT) of the Pouteria torta subsp. torta seeds submitted to the temperatures of 20, 25, 30, 35, 2030 and $25-35^{\circ} \mathrm{C}$ on two substrates (paper and vermiculite)

Tabela 1. Análise de variância, germinação (G\%), índice de velocidade de germinação (IVG) e tempo médio de germinação em dias (TMG) de sementes de Pouteria torta subesp. torta, submetidas às temperaturas de $20,25,30,35,20-30$ e $25-35^{\circ} \mathrm{C}$, sobre dois substratos (papel e vermiculita)

\begin{tabular}{|c|c|c|c|c|c|c|}
\hline \multicolumn{7}{|c|}{ G\% } \\
\hline Source of variation & G. L. & \multicolumn{2}{|c|}{ Sum of squares } & Medium square & \multicolumn{2}{|c|}{$\mathbf{F}$} \\
\hline Substrate (F1) & 1 & \multicolumn{2}{|c|}{500.52083} & 500.52083 & \multicolumn{2}{|c|}{$465.0000 * *$} \\
\hline Temperature (F2) & 5 & \multicolumn{2}{|c|}{389.60417} & 77.92083 & \multicolumn{2}{|c|}{$72.3910 * *$} \\
\hline Interaction $\mathrm{F} 1 \mathrm{xF} 2$ & 5 & \multicolumn{2}{|c|}{132.60417} & 26.52083 & \multicolumn{2}{|c|}{$24.6387 * *$} \\
\hline Treatments & 11 & \multicolumn{2}{|c|}{1022.72917} & 92.97538 & \multicolumn{2}{|c|}{$86.3771 * *$} \\
\hline Residuals & 36 & \multicolumn{2}{|c|}{38.75000} & 1.07639 & & \\
\hline Total & 47 & \multicolumn{2}{|c|}{1061.47917} & & & \\
\hline Germination (\%) & $20^{\circ} \mathrm{C}$ & $25^{\circ} \mathrm{C}$ & $30{ }^{\circ} \mathrm{C}$ & $35^{\circ} \mathrm{C}$ & $20-30{ }^{\circ} \mathrm{C}$ & $25-35{ }^{\circ} \mathrm{C}$ \\
\hline On vermiculite & $24 \mathrm{aB}$ & $28 \mathrm{aB}$ & $24 \mathrm{aB}$ & $60 \mathrm{aA}$ & $32 \mathrm{aB}$ & $64 \mathrm{aA}$ \\
\hline On paper & $4 \mathrm{bCD}$ & $16 \mathrm{bB}$ & $8 \mathrm{bC}$ & $4 \mathrm{bD}$ & $8 \mathrm{bC}$ & $32 \mathrm{bA}$ \\
\hline \multirow[t]{2}{*}{ LSD } & \multicolumn{3}{|c|}{ Column } & \multicolumn{3}{|c|}{ Line } \\
\hline & \multicolumn{3}{|c|}{$1.49(p<0.01)$} & \multicolumn{3}{|c|}{$2.61(p<0.01)$} \\
\hline
\end{tabular}

FLORESTA, Curitiba, PR, v. 50, n. 1, p. 923 - 924, jan/mar 2020

Pina, J. C. et.al.

ISSN eletrônico 1982-4688 


\begin{tabular}{|c|c|c|c|c|c|c|}
\hline \multicolumn{7}{|c|}{ GSI } \\
\hline Source of variation & G. L. & \multicolumn{2}{|c|}{ Sum of squares } & Medium square & \multicolumn{2}{|c|}{$\mathbf{F}$} \\
\hline Substrate (F1) & 1 & \multicolumn{2}{|c|}{3.89880} & 3.89880 & \multicolumn{2}{|c|}{$1233.3638 * *$} \\
\hline Temperature (F2) & 5 & \multicolumn{2}{|c|}{5.19367} & 1.03873 & \multicolumn{2}{|c|}{$328.5975 * *$} \\
\hline Interaction $\mathrm{F} 1 \mathrm{xF} 2$ & 5 & \multicolumn{2}{|c|}{2.48690} & 0.49738 & \multicolumn{2}{|c|}{$157.3434 * *$} \\
\hline Treatments & 11 & \multicolumn{2}{|c|}{11.57937} & 1.05267 & \multicolumn{2}{|c|}{$333.0062 * *$} \\
\hline Residuals & 36 & \multicolumn{2}{|c|}{0.11380} & 0.00316 & & \\
\hline Total & 47 & \multicolumn{2}{|c|}{11.69317} & & & \\
\hline GSI & $20{ }^{\circ} \mathrm{C}$ & $25^{\circ} \mathrm{C}$ & $30{ }^{\circ} \mathrm{C}$ & $35^{\circ} \mathrm{C}$ & $20-30{ }^{\circ} \mathrm{C}$ & $25-35{ }^{\circ} \mathrm{C}$ \\
\hline On vermiculite & $0.50 \mathrm{aC}$ & $0.60 \mathrm{aBC}$ & $0.65 \mathrm{aBC}$ & $1.86 \mathrm{aA}$ & $0.72 \mathrm{aB}$ & $1.4 \mathrm{aA}$ \\
\hline On paper & $0.09 \mathrm{bD}$ & $0.31 \mathrm{bB}$ & $0.33 \mathrm{bB}$ & $0.14 \mathrm{bCD}$ & $0.22 \mathrm{bBC}$ & $1.06 \mathrm{bA}$ \\
\hline \multirow[t]{2}{*}{ LSD } & \multicolumn{3}{|c|}{ Column } & \multicolumn{3}{|c|}{ Line } \\
\hline & \multicolumn{3}{|c|}{$0.081(p<0.01)$} & \multicolumn{3}{|c|}{$0.120(p<0.01)$} \\
\hline
\end{tabular}

MGT

\begin{tabular}{|c|c|c|c|c|c|c|}
\hline Source of variation & G. L. & \multicolumn{2}{|c|}{ Sum of squares } & Medium square & \multicolumn{2}{|c|}{$\mathbf{F}$} \\
\hline Substrate (F1) & 1 & \multicolumn{2}{|c|}{1132.96333} & 1132.96333 & \multicolumn{2}{|c|}{$441.1040 * *$} \\
\hline Temperature (F2) & 5 & \multicolumn{2}{|c|}{2033.14417} & 406.62883 & \multicolumn{2}{|c|}{$158.3154 * *$} \\
\hline Interaction $\mathrm{F} 1 \mathrm{xF} 2$ & 5 & \multicolumn{2}{|c|}{1095.08667} & 219.01733 & \multicolumn{2}{|c|}{$85.2714 * *$} \\
\hline Treatments & 11 & \multicolumn{2}{|c|}{4261.19417} & 387.38129 & & \\
\hline Residuals & 36 & \multicolumn{2}{|c|}{92.46500} & 2.56847 & & \\
\hline Total & 47 & \multicolumn{2}{|c|}{4353.65917} & & & \\
\hline MGT & $20{ }^{\circ} \mathrm{C}$ & $25^{\circ} \mathrm{C}$ & $30{ }^{\circ} \mathrm{C}$ & $35^{\circ} \mathrm{C}$ & $20-30{ }^{\circ} \mathrm{C}$ & $25-35{ }^{\circ} \mathrm{C}$ \\
\hline On vermiculite & $50.7 \mathrm{aB}$ & $48.3 \mathrm{aB}$ & $43.8 \mathrm{bB}$ & $36.7 \mathrm{bA}$ & $47 \mathrm{bB}$ & $48.9 \mathrm{bB}$ \\
\hline On paper & $47 \mathrm{aD}$ & $54.8 \mathrm{bD}$ & $24.5 \mathrm{aA}$ & $28 \mathrm{aAB}$ & $36 \mathrm{aC}$ & $31.9 \mathrm{aBC}$ \\
\hline \multirow[t]{2}{*}{ LSD } & \multicolumn{3}{|c|}{ Column } & \multicolumn{3}{|c|}{ Line } \\
\hline & \multicolumn{3}{|c|}{$2.30(p<0.01)$} & \multicolumn{3}{|c|}{$3.41(p<0.01)$} \\
\hline
\end{tabular}

$* *$ Significant at $1 \%$ probability level $(p<0.01)$; LSD = value of the least significant difference for the chosen test; LSD = TSD (Tukey Significant Difference); Means followed by the same lowercase letter in the column and uppercase letter in the row do not differ statistically by Tukey's test $(p>0.05)$.

Approximately $60 \%$ of the seeds maintained at the temperatures of 20 and $20-30{ }^{\circ} \mathrm{C}$ on paper substrate were considered viable and approximately $40 \%$ of those kept at the temperatures of 20,25 and $30{ }^{\circ} \mathrm{C}$ on vermiculite substrate were viable. These were the groups with the largest number of viable and non-germinated seeds (Table 2).

In contrast, the temperatures of $25,30,35$ and $25-35{ }^{\circ} \mathrm{C}$ on paper substrate showed a number of nonviable (dead) seeds $\geq 60 \%$, and the temperatures of $20,25,30$ and $20-30{ }^{\circ} \mathrm{C}$ on vermiculite substrate presented between 32 and $40 \%$ of non-viable seeds (Table 2).

Table 2. Viable, non-viable and germinated seeds (\%) of the Pouteria torta subsp. torta submitted to the temperatures of $20,25,30,35,20-30$ and $25-35{ }^{\circ} \mathrm{C}$ on two substrates (paper and vermiculite)

Tabela 2. Sementes viáveis, inviáveis e germinadas (\%) de Pouteria torta subesp. torta, submetidas às temperaturas de $20,25,30,35,20-30$ e $25-35^{\circ} \mathrm{C}$, sobre dois substratos (papel e vermiculita)

\begin{tabular}{ccccccccc}
\hline & \multicolumn{3}{c}{ On paper } & \multicolumn{4}{c}{ On vermiculite } \\
\hline \multirow{2}{*}{$\mathrm{T}{ }^{\circ} \mathrm{C}$} & $\begin{array}{c}\text { Viable } \\
(\%)\end{array}$ & $\begin{array}{c}\text { Non-viable } \\
(\%)\end{array}$ & $\begin{array}{c}\text { Total } \\
(\%)\end{array}$ & $\begin{array}{c}\text { Germinated } \\
(\%)\end{array}$ & $\begin{array}{c}\text { Viable } \\
(\%)\end{array}$ & $\begin{array}{c}\text { Non-viable } \\
(\%)\end{array}$ & $\begin{array}{c}\text { Total } \\
(\%)\end{array}$ & $\begin{array}{c}\text { Germinated } \\
(\%)\end{array}$ \\
\hline 20 & 60 & 36 & 96 & 4 & 40 & 36 & 76 & 24 \\
25 & 16 & 68 & 84 & 16 & 40 & 32 & 72 & 28 \\
30 & 16 & 76 & 92 & 8 & 40 & 36 & 76 & 24 \\
35 & - & 96 & 96 & 4 & 12 & 28 & 40 & 60 \\
$20-30$ & 60 & 32 & 92 & 8 & 28 & 40 & 68 & 32 \\
$25-35$ & 8 & 60 & 68 & 32 & 20 & 16 & 36 & 64 \\
\hline
\end{tabular}


The primary root protrusion process began after 20 days of testing at the temperatures $25-35{ }^{\circ} \mathrm{C}$ (paper) and $35^{\circ} \mathrm{C}$ (vermiculite), followed by on the $24^{\text {th }}$ day at $30^{\circ} \mathrm{C}$ (paper and vermiculite), on the $28^{\text {th }}$ day at $35^{\circ} \mathrm{C}$ (paper), and on the $29^{\text {th }}$ day at $25-35^{\circ} \mathrm{C}$ (vermiculite).

Lower temperatures enabled longer protrusion time, with the temperature of $20{ }^{\circ} \mathrm{C}$ promoting primary root protrusion on the $36^{\text {th }}$ (vermiculite) and $47^{\text {th }}$ (paper) days, $25^{\circ} \mathrm{C}$ on the $36^{\text {th }}$ day (paper and vermiculite), and 20-30 ${ }^{\circ} \mathrm{C}$ on the $36^{\text {th }}$ day (paper and vermiculite).

Regarding the relative frequency, germination was not synchronized, presenting a distribution over the incubation time and heterogeneous for all treatments (Figure 1).
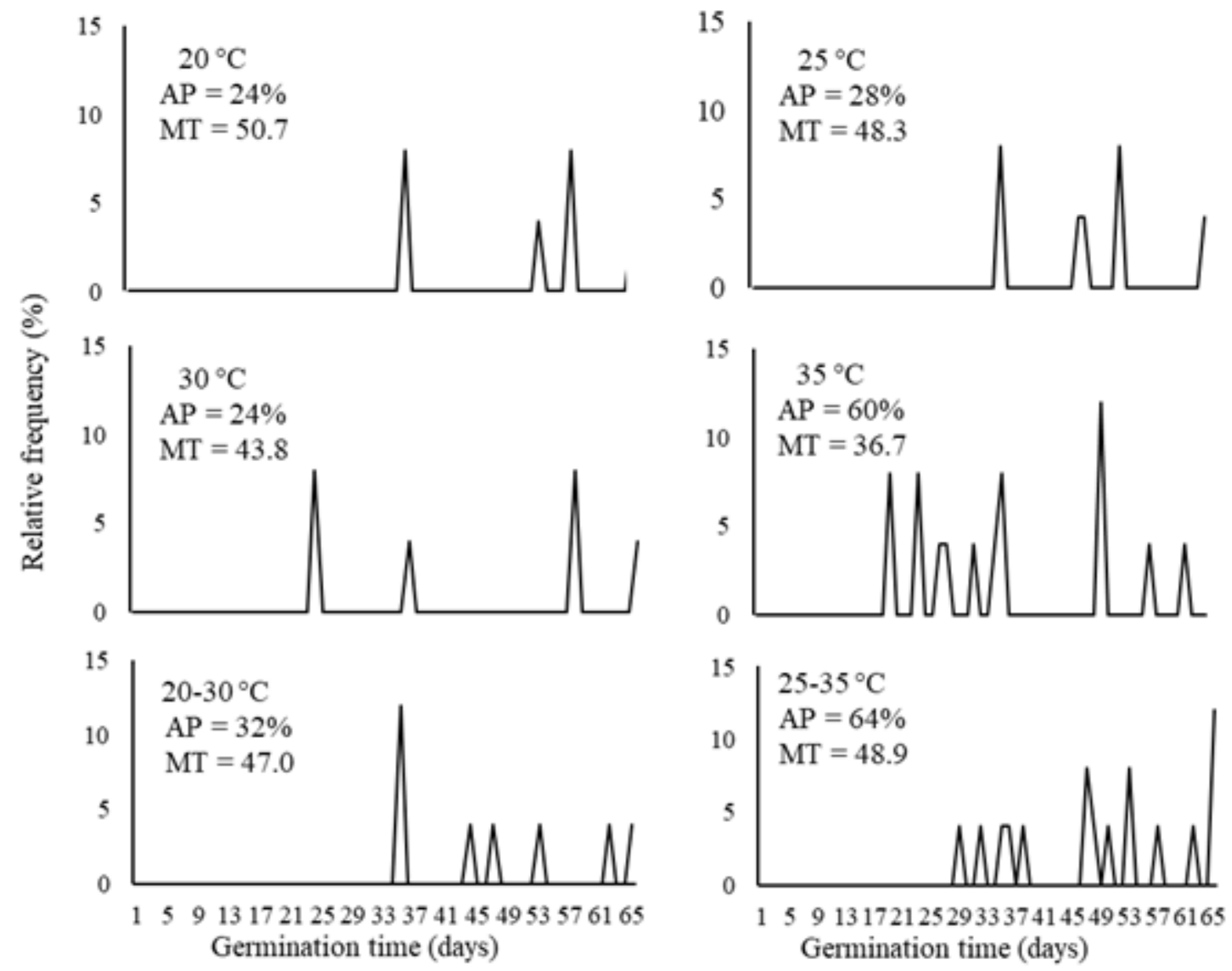

Figure 1. Relative frequency of germination of Pouteria torta subsp. torta seeds submitted to treatment on vermiculite and different temperatures in germination chamber. AP = Average percentage of germinated seeds; MGT = mean germination time (days).

Figura 1. Frequência relativa de germinação de sementes de Pouteria torta subesp. torta submetidas ao tratamento sobre vermiculita e diferentes temperaturas em câmara de germinação. PG = porcentagem média de sementes germinadas e TM = tempo médio (dias) de germinação.

\section{Seedling Formation}

On the paper substrate, germinated seeds (primary root protrusion) at all temperatures tested did not form normal seedlings. On the vermiculite substrate, the temperatures of 20 and $25{ }^{\circ} \mathrm{C}$ also did not provide the formation of normal seedlings (Table 3 ).

The temperatures of $30,35,20-30$ and $25-35{ }^{\circ} \mathrm{C}$ (vermiculite) allowed the formation of complete seedlings, with the best percentages occurring at 35 and $25-35^{\circ} \mathrm{C}$, which also generated the largest seedlings (Table 3). 
Table 3. Germination (\%), normal seedlings (NS) (\%), and root and shoot growth (mm) of seeds of Pouteria torta subsp. torta kept on two substrates, paper $(\mathrm{P})$ and vermiculite $(\mathrm{V})$, at the temperatures of 20, 25, 30, 35, 20-30 and $25-35{ }^{\circ} \mathrm{C}$

Tabela 3. Sementes germinadas (\%), plântulas normais (\%) e crescimento da raiz e parte aérea (mm) de sementes de Pouteria torta subesp. torta mantidas sobre dois substratos, papel e vermiculita, temperaturas de 20 , $25,30,35,20-30$ e $25-35{ }^{\circ} \mathrm{C}$

\begin{tabular}{ccccccccc}
\hline $\mathrm{T}{ }^{\circ} \mathrm{C}$ & $\begin{array}{c}\text { Germination P } \\
(\%)\end{array}$ & $\begin{array}{c}\text { NS } \\
(\%)\end{array}$ & $\begin{array}{c}\text { Root } \\
(\mathrm{mm})\end{array}$ & $\begin{array}{c}\text { Shoot } \\
(\mathrm{mm})\end{array}$ & $\begin{array}{c}\text { Germination V } \\
(\%)\end{array}$ & $\begin{array}{c}\text { NS } \\
(\%)\end{array}$ & $\begin{array}{c}\text { Root } \\
(\mathrm{mm})\end{array}$ & $\begin{array}{c}\text { Shoot } \\
(\mathrm{mm})\end{array}$ \\
\hline 20 & 4 & 0 & - & - & 24 & 0 & - & - \\
25 & 16 & 0 & - & - & 28 & 0 & - & - \\
30 & 8 & 0 & - & - & 24 & $8 \mathrm{~b}$ & $13.8 \mathrm{a}$ & $1.5 \mathrm{~b}$ \\
35 & 4 & 0 & - & - & 60 & $32 \mathrm{a}$ & $11.8 \mathrm{a}$ & $3.2 \mathrm{a}$ \\
$20-30$ & 8 & 0 & - & - & 32 & 16 & $5.5 \mathrm{~b}$ & $0.9 \mathrm{~b}$ \\
$25-35$ & 32 & 0 & - & - & 64 & $28 \mathrm{a}$ & $10.5 \mathrm{a}$ & $2.0 \mathrm{ab}$ \\
\hline
\end{tabular}

*Means followed by the same lower case letter in the column do not differ statistically by the Tukey's test ( $p>0.05)$.

\section{DISCUSSION}

\section{Water content}

The water content found $(36.2 \%)$ is generally associated with species considered sensitive to desiccation, in which moisture loss would lead to decreased viability, with seed deterioration occurring in a short time (BEWLEY et al., 2013). Recent research indicates that differences in desiccation tolerance may depend on the degree of maturation before dispersion (BARBEDO et al., 2013; BEWLEY et al., 2013). According to Carvalho (2008), the longevity of Pouteria torta seeds is very short, with rapid loss of vigor after harvest and seeds presenting recalcitrant characteristics, with water loss leading to physiological damage.

Salomão et al. (2003) reported a value $43 \%$ of water content for $P$. torta, similar to that found in this study, but did not identified the subspecies evaluated. Other species of the same genus showed higher values, such as $46 \%$ for $P$. ramiflora (SALOMÃO et al., 2003) and $47.2 \%$ for $P$. campechiana (Kunth) Baehni (COSTA et al., 2010). The values mentioned indicate that seeds of genus Pouteria may have high water content, perhaps a characteristic of this genus, which would provide germination in a short time and rapid loss of viability. Salomão et al. (2003) and Carvalho (2008) recommended that the seeds of Pouteria torta be placed to germinate when freshly harvested to obtain good germination because their viability is short.

According to Salomão et al. (2003), other seeds of Cerrado species also present similar behavior, with high water content, such as Campomanesia adamantium (Cambess.) O. Berg., Eugenia dysenterica DC (Myrtaceae) and Hancornia speciosa Gomez (Apocynaceae). According to Barbedo et al. (2013) and Bewley et al. (2013), species with high water content usually originate from habitats that allow rapid seed establishment after dispersal of the mother plant, which represents an evolutionary adaptation of these species. However, this situation was not observed for Pouteria torta subesp. torta, because the species distributes its germination period over several weeks (high MGT).

\section{Germination}

According to Carvalho (2008), species germination is hypogeal or cryptocotyledon, which was observed in this study. The morphofunctional types of germination and seedlings described for other species of this genus, such as P. fimbriata Baehni, P. multiflora (A.DC.) Eyma and P. macrophylla (Lam.) Eyma present hypogeal germination (VILLACHICA et al., 1996). Camargo et al. (2008) also reported the same for P. guianensis Aubl. and some other species of this family. In contrast, $P$. jariensis Pires \& T. D. Penn. presented phanerocotyledon seedlings, but with epigeal germination. The germination pattern of a species is determined by the environment and its establishment strategies, which may vary depending on the place of origin. Thus, result discrepancies may occur in studies on seeds of the same species from different lots.

\section{Root protrusion onset and relative frequency}

Primary root protrusion began at higher temperatures $\left(30,35\right.$ and $\left.25-35^{\circ} \mathrm{C}\right)$, whereas lower temperatures $\left(20,25\right.$ and $\left.20-30^{\circ} \mathrm{C}\right)$ provided longer protrusion time. The results, under the best conditions, are similar to those 
described by Carvalho (2008), with emergence occurring between 25 and 50 days after seeding. Villachica et al. (1996) observed, for P. macrophylla, beginning of germination 24 days after the beginning of the experiment, indicating slow and uneven germination of the evaluated species. These reports suggest the presence of seed coat on dormancy, and this characteristic, associated with inadequate substrate, may be responsible for failure in the emergence process. Low germination speed and seedling emergence uncertainty may be characteristic of the species under natural conditions.

The relative germination frequency was not synchronized, with distribution over the incubation time and heterogeneous for all temperatures. As seed germination is not fully synchronized, it was possible to verify a series of temporal variations in this species (Figure 1), starting from the $20^{\text {th }}$ day and extending to the $65^{\text {th }}$ day, demonstrating their distribution over time. The frequency distribution for P. torta subsp. Torta, the delay in germination, and its temporal distribution suggest seed adaptation to increase the probability of survival in highly heterogeneous habitats such as the Cerrado.

Oliveira and Nunes (2013), evaluating the seed germination of Rheedia brasiliensis (Mart.) Planch. \& Triana collected in flooded areas and Oliveira et al. (2014), assessing the seed germination of Miconia albicans (Sw.) Triana obtained in Cerrado areas, also demonstrated long temporal distribution in germination, and correlated this event with the place of collection, which presented variations in their environmental conditions. This behavior may be important for germination distribution (BRANCALION; MARCOS FILHO, 2008), a strategy that provides greater efficiency in seedling establishment, as it can meet ideal conditions at some point.

\section{Germination percentages}

Brancalion et al. (2010), performing a review of existing information at the best temperatures for seed germination of Cerrado biome species, reported that most of the species surveyed germinate better between 25 and $30{ }^{\circ} \mathrm{C}$, with higher concentration around $25^{\circ} \mathrm{C}$. Pouteria torta subsp. torta presented a different germination behavior. The results indicated that, considering that the most important is the germination of a larger number of seeds in a shorter time (high vigor), the best treatment for the species in question is the vermiculite substrate at the temperatures of 35 and $25-35^{\circ} \mathrm{C}$, with 60 and $64 \%$ germination, respectively.

Significant results with the use of vermiculite were also reported by Bassaco et al. (2014) with seeds of Sebastiania brasiliensis Spreng. and by Pereira et al. (2015) with Moringa oleifera Lam., in which this substrate provided better germination and growth, demonstrating its suitability to germination tests. The large water retention capacity and greater contact area of the vermiculite substrate were probably the factors that contributed to a higher germination percentage of Pouteria torta subsp. torta seeds compared with the paper substrate.

Although a good germination rate has occurred at certain temperatures $\left(35\right.$ e $\left.25-35{ }^{\circ} \mathrm{C}\right)$, vermiculite substrate, at the end of the experiment viable seeds still existed (Table 2), demonstrating that the germination process could continue to occur, increasing the final germination percentage. These results may indicate some kind of numbness, integumentary or embryonic.

In the best conditions, germination $>25 \%$ was obtained, reaching $60 \%$ (vermiculite, $35{ }^{\circ} \mathrm{C}$ ) or $64 \%$ (vermiculite, $25-35{ }^{\circ} \mathrm{C}$ ), with 12 and $20 \%$ of viable and non-germinated seeds, respectively.

According to Monteiro et al. (2007), seeds of Pouteria torta have sturdy coat. Salomão et al. (2003) describe values between 20 and $23 \%$ dormancy and $25 \%$ germination. The possible dormancy reported may be exogenous due to the impermeability of the integument to water or gases, and may be interrupted by processes that cause rupture of the integument, allowing water absorption and germination, as at high temperatures.

Results indicate that high temperatures would be more propitious to obtain higher germination rates, enabling the seed rehydration process or acting as a sign of environmental conditions (BEWLEY et al., 2013). Pereira et al. (2013), evaluating seeds of Peltophorum dubium (Spreng.) Taub., confirmed that relatively high temperatures $\left(35^{\circ} \mathrm{C}\right.$ ) are essential to overcome the dormancy of the species. Zucareli et al. (2015), assessing the germination of Passiflora incarnata L., also demonstrated that the temperature of $35^{\circ} \mathrm{C}$ was the most appropriate for seed germination, corroborating the results found in the present study.

The alternating temperature of $25-35^{\circ} \mathrm{C}$ was also effective to accelerate species germination. According to Brancalion et al. (2008), alternating temperature regimes may be associated with overcoming the impermeability of the integument to water, allowing seed hydration and germination. Masin et al. (2017) confirmed that the use of alternating temperatures is adequate to obtain good germination rates.

According to Liu et al. (2013) and De Vitis et al. (2014), these temperatures indicate that the species is adapted to succession environments, such as in clearings, where pioneer species occur at the early stages and seeds

FLORESTA, Curitiba, PR, v. 50, n. 1, p. 923 - 924, jan/mar 2020.

Pina, J. C. et.al.

ISSN eletrônico 1982-4688 
may require alternating temperatures to optimize germination. In contrast, Yu et al. (2008) reported that, for some species in clearing environments, light variations interfered with germination behavior, whereas for others, light differences did not affect germination. This need probably reflects an adaptation to natural habitat fluctuation or may be associated with the dormancy process. Whatever the cause, this requirement can, in most cases, provide species with an adaptive advantage.

Regarding the lower vigor found at lower temperatures, the results could be expected because, according to Bewley et al. (2013), a decrease in temperature slows down metabolic activities, causing reduction in germination percentage and delay in the germination process. However, the temperature of $30{ }^{\circ} \mathrm{C}$, for example, would not be considered low (Table 2). As previously stated, higher temperatures may provide higher gas and water diffusion rates, inducing better germination.

The lower germination performance on paper treatments, $\leq 16 \%$ germination, except for $25-35{ }^{\circ} \mathrm{C}$, which reached $32 \%$ (also a small rate), may be related to its characteristics, which allow less seed contact with the substrate, leaving it more exposed to water restriction, mainly due to its size, considered large by Carvalho (2008). According to Brazil (2009) and Bewley et al. (2013), water availability in the substrate and its variation, a common factor in this type of work, often causes reduction in germination values because water reactivates metabolism and is directly and indirectly involved in all stages of the germination process. Of the substrates used, paper had the lowest water retention and seed contact capacity, resulting in smaller germination and vigor mean values.

\section{Seedling formation}

As for analysis of the seedlings, the use of vermiculite allowed the formation of complete seedlings at the temperatures of $30,35,20-30$ and $25-35{ }^{\circ} \mathrm{C}$, with emphasis on 35 and $25-35{ }^{\circ} \mathrm{C}$, which also showed the highest average growth. The results showed that higher temperatures are needed for germination and formation of normal seedlings in a shorter time, a situation confirmed by the evaluation of non-germinated seeds, with a larger number occurring at $20^{\circ} \mathrm{C}$. Exposure of seeds to low temperatures, such as $20^{\circ} \mathrm{C}$, even for a $12 \mathrm{~h}$ photoperiod, led to lower germination and growth rates, indicating sensitivity of the seeds to this situation.

According to the study conducted by Oliveira and Jardim (2013) with P. ramiflora seeds, emergence occurred as of the $28^{\text {th }}$ day after sowing, extending to the $114^{\text {th }}$ day, and reaching $75 \%$ germination, results similar to the findings of this study. The data showed that the process of germination and seedling formation is long and may be a characteristic of the genus Pouteria.

Regarding the substrates, paper was not suitable, not allowing the formation of normal seedlings at any temperature tested, whereas vermiculite provided formation of normal seedlings probably because of its good structure and high water retention capacity, being the most suitable substrate for this species.

\section{CONCLUSION}

Considering the analyzed variables (germination, germination speed index, and formation of normal seedlings), the temperatures of 35 and $25-35^{\circ} \mathrm{C}$ and the vermiculite substrate are the most suitable for the production of Pouteria torta subesp. torta seedlings.

\section{ACKNOWLEDGMENTS}

The authors are grateful to CAPES, for the postgraduate scholarship; to CNPq, for the grant in research productivity; to CNPq and FUNDECT for the financial support; to Anhanguera-Uniderp University for the funding of the Interdisciplinary Research Group.

\section{REFERENCES}

BARBEDO, C. J.; CENTENO, D. C.; FIGUEIREDO-RIBEIRO, R. C. L. Do recalcitrant seeds really exist? Hoehnea, São Paulo, v. 40, n. 4, p. 583-593, 2013.

BASSACO, M. V. M.; NOGUEIRA, A. C.; COSMO, N. L. Avaliação da germinação em diferentes temperaturas e substratos e morfologia do fruto, semente e plântula de Sebastiania brasiliensis. Revista Floresta, Curitiba, v. 44, n. 3, p. 381-392, 2014.

BEWLEY, J. D.; BRADFORD, K.; HILHORST, H.; NONOGAKI, H. Seeds: physiology of development, germination and dormancy. 3ed. New York: Springer eBooks, 2013, 392 p. 
BRANCALION, P. H. S.; MARCOS FILHO, J. Distribuição da germinação no tempo: causas e importância para a sobrevivência das plantas em ambientes naturais. Informativo ABRATES, Londrina, v. 18, n. 1, 2, 3, p. 11 17, 2008.

BRANCALION, P. H. S.; NOVEMBRE, A. D. L. C.; RODRIGUES, R. R. Temperatura ótima de germinação de sementes de espécies arbóreas brasileiras. Revista Brasileira de Sementes, Londrina, v. 32, n. 4, p. 15 - 21, 2010.

BRASIL. Ministério da Agricultura, Pecuária e Abastecimento. Regras para análise de sementes. Ministério da Agricultura, Pecuária e Abastecimento. Secretaria de Defesa Agropecuária. Brasília: Mapa/ACS, 2009, 395 p.

CAMARGO, J. L. C.; FERRAZ, I.; MESQUITA, M.; SANTOS, B.; BRUN, H. Guia de propágulos e plântulas da Amazônia. Manaus: INPA, 2008, 168 p.

CARVALHO, P. E. R. Espécies arbóreas brasileiras. Vol.3. Brasília: Embrapa Informação Tecnológica; Colombo: Embrapa Florestas, 2008, 593 p.

COSTA, T. S. A.; WONDRACEK, D. C.; LOPES, R. M.; VIEIRA, R. F.; FERREIRA, F. R. Composição de carotenoides em canistel (Pouteria campechiana (Kunth) Baehni). Revista Brasileira de Fruticultura, Jaboticabal, v. 32, n. 3, p. 903-906, 2010.

DE VITIS, M.; SEAL, C. E.; ULIAN, T.; PRITCHARD, H. W.; MAGRINI, S.; FABRINI, G.; MATTANA, E. Rapid adaptation of seed germination requirements of the threatened Mediterranean species Malcolmia littorea (Brassicaceae) and implications for its reintroduction. South African Journal of Botany, Elsevier, v. 94, p. 4650, 2014.

DOUSSEAU, S.; ALVARENGA, A. A.; ARANTES, L. O.; OLIVEIRA, D. M.; NERY, F. C. Germinação de sementes de tanchagem (Plantago tomentosa Lam.): influência da temperatura, luz e substrato. Ciência e Agrotecnologia, Lavras, v. 32, n. 2, p. 438-443, 2008.

ELIAS, S. T.; SALLES, P. M.; PAULA, J. E.; SIMEONI, L. A.; SILVEIRA, D.; GUERRA, E. N.; MOTOYAMA, A. B. Cytotoxic effect of Pouteria torta leaf extracts on human oral and breast carcinomas cell lines. Journal of Cancer Research and Therapeutics, Mumbai, v. 9, n. 4, p. 601-606, 2013.

GRECCHI, R. C.; GWYN, Q. H. J.; BÉNIÉ, G. B.; FORMAGGIO, A. R.; FAHL, F. C. Land use and land cover changes in the Brazilian Cerrado: A multidisciplinary approach to assess the impacts of agricultural expansion. Applied Geography, Elsevier, v. 55, p. 300-312, 2014.

LIU, K.; BASKIN, J. M.; BASKIN, C. C.; BU, H.; DU, G.; MA, M. Effect of diurnal fluctuating versus constant temperatures on germination of 445 species from the Eastern Tibet Plateau. PLoS ONE, São Francisco, v. 8, n. 7 , p. e69364, 2013.

MASIN, R.; ONOFRI, A.; GASPARINI, V.; ZANIN. G. Can alternating temperatures be used to estimate base temperature for seed germination? Weed Research, Wiley, v. 57, n. 6, p. 390-398, 2017.

MONTEIRO, M. H. D. A.; NEVES, L. J.; ANDREATA, R. H. P. Taxonomia e anatomia das espécies de Pouteria aublet (Sapotaceae) do Estado do Rio de Janeiro, Brasil. Pesquisas Botânica, São Leopoldo, v. 58, [s. n.], p. 7 118, 2007.

OLIVEIRA, A. K. M.; NUNES, A. C. Superação de dormência em sementes de Rheedia brasiliensis. Científica, Jaboticabal, v. 41, n. 2, p. 246-250, 2013.

OLIVEIRA, A. K. M.; MOTA, C. M. G.; AGNES, D. C. Efeito de diferentes temperaturas na germinação de sementes e no crescimento inicial de plântulas de Miconia albicans (Melastomataceae). Revista Brasileira de Plantas Medicinais, Campinas, v. 16, n. 3, supl. I, p. 755-759, 2014.

OLIVEIRA, F. G.; JARDIM, M. A. G. Emergência de Acacia farnesiana (L.) Willd. (Fabaceae) e Pouteria ramiflora radlk. (Sapotaceae) em diferentes substratos. REVSBAU, Piracicaba, v. 8, n. 4, p. 1-7, 2013.

PEREIRA, S. R.; KALIFE, C.; RODRIGUES, A. P. D. A. C.; LAURA, V. A. Influência da temperatura na germinação de sementes de Peltophorum dubium (Spreng.) Taub. Informativo Abrates, Londrina, v. 23, n. 3, p. $52-55,2013$.

PEREIRA, K. T. O.; SANTOS, B. R. V.; BENEDITO, C. P.; LOPES, E. G.; AQUINO, G. S. M. Germinação e vigor de sementes de Moringa oleifera Lam. em diferentes substratos e temperaturas. Revista Caatinga, Mossoró, v. 28, n.2, p.92-99, 2015. 
SALOMÃO, N. A.; SILVA, J. C. S.; DAVIDE, A. C.; GONZALES, S.; TORRES, R. A. A.; WETZEL, M. M. V. S.; FIRETTI, F.; CALDAS, L. S. Germinação de sementes e produção de mudas de plantas do Cerrado. Brasília: Rede de Sementes do Cerrado, 2003, 96 p.

VILLACHICA, H.; CARVALHO, J. E. U.; MULLER, C. H.; DIAZ, S. C.; ALMANZA, M. Frutales y hortalizas promisorios de la Amazonia. Lima: Tratado de Cooperación Amazonica, 1996, 367 p.

ZUCARELI, V.; HENRIQUE, L. A. V.; ONO, E. O. Influence of light and temperature on the germination of Passiflora incarnata L. seeds. Journal of Seed Science, Londrina, v. 37, n. 2, p. 162-167, 2015.

YU, Y.; BASKIN, J. M.; BASKIN, C. C.; TANG, Y.; CAO, M. Ecology of seed germination of eight non-pioneer tree species from a tropical seasonal rain forest in southwest China. Plant Ecology, Amsterdam, v. 197, n. 1, p. 1$16,2008$. 